\title{
ARTICLES
}

MICHAEL KARANICOLAS*

\section{Even in a Pandemic, Sunlight Is the Best Disinfectant: COVID-19 and Global Freedom of Expression}

I. Misinformation Laws and Human Rights ................................. 2

II. From a Public Health Crisis to a Human Rights Crisis............. 6

III. Protecting Speech in Times of Crisis .................................... 10

IV. Assessing Global Responses .............................................. 12

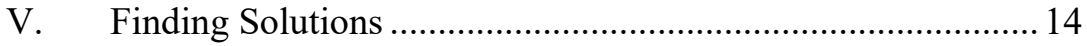

A. Narrowing and Clarifying the Prohibitions ..................... 14

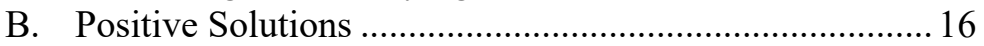

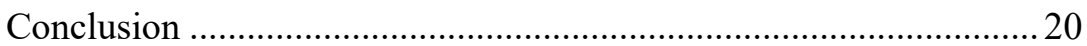

Tn times of war, the right to speak freely is often the first casualty. ${ }^{1}$ As global leaders use the language of war to describe their efforts to stop COVID- $19,{ }^{2}$ an implication exists that, as in wartime, the current

\footnotetext{
* Drafted by Michael Karanicolas, Wikimedia Fellow - Information Society Project (ISP), Yale Law School, with supporting research from ISP Summer Students Tomiwa Ilori, Ayesha Khan, and Juan Carlos Salamanca. Thanks to Molly Land and Jack Balkin, as well as to my colleagues at Yale ISP: Thomas Kadri, Niklas Eder, Jisu Kim, Francesca Procaccini, Nikolas Guggenberger, Przemyslaw Palka, Arturo Monteiro, Carlos Liguori, Maren Woebbeking, Bonnie Kaplan, and Leah Ferentinos, for their helpful feedback and commentary.

1 See, e.g., Thomas I. Emerson, Freedom of Expression in Wartime, 116 U. PA. L. REV. 975 (1968).

2 Caitlin Oprysko \& Susannah Luthi, Trump Labels Himself 'a Wartime President' Combating Coronavirus, POLITICO (Mar. 18, 2020), https://www.politico.com/news/2020 /03/18/trump-administration-self-swab-coronavirus-tests-135590; Xi Focus: Moment of
} 
crisis demands exceptional limitations on freedom of expression. In the name of public health, governments around the world have enacted new policies targeting misinformation or increased enforcement of existing rules over the course of the pandemic. ${ }^{3}$ While the World Health Organization warns of an "infodemic" of fake news that "spreads faster and more easily than this virus," ${ }^{4}$ human rights advocates express alarm at the effects of the accompanying crackdown on freedom of expression. ${ }^{5}$

This Article discusses the global human rights implications of aggressive measures targeting the spread of COVID-19-related misinformation. Part I discusses the international human rights standards regarding misinformation. Part II explores various regulatory responses to misinformation about COVID-19, thus showing the impact on international human rights. Part III explores the applicability of international human rights law, specifically the standards for derogation in key human rights documents, to the current exceptional circumstances of COVID-19. Part IV assesses the regulatory responses against international human rights standards, finding significant cause for concern, particularly if these enforcement postures become normalized. Part $\mathrm{V}$ offers alternative solutions to the human rights challenges posed by health misinformation, particularly restrictions that are more carefully targeted and less open to abuse as well as transparency measures to promote trust and accountability in public institutions.

\section{I}

\section{MISINFORMATION LAWS AND HUMAN RIGHTS}

Laws that prohibit the spread of misinformation raise a number of freedom of expression concerns. First, what constitutes misinformation

Truth: Xi Leads War Against COVID-19, XINHUA (Mar. 10, 2020), http://www.xinhuanet .com/english/2020-03/10/c_138863611.htm [https://perma.cc/4HZ2-ET87].

3 David Kaye (Special Rapporteur on the Promotion and Prot. of the Right to Freedom of Opinion and Expression), Disease Pandemics and the Freedom of Opinion and Expression, Rep. of the U.N. Hum. Rts. Council on its Forty-Fourth Session, June 15-July 3, 2020, ๆๆ 48-49, U.N. Doc. A/HRC/44/49 (2020).

4 UN Tackles 'Infodemic' of Misinformation and Cybercrime in COVID-19 Crisis, UNDGC (Mar. 31, 2020), https://www.un.org/en/un-coronavirus-communications-team /un-tackling-'infodemic'-misinformation-and-cybercrime-covid-19 [https://perma.cc/GE69 $-4 \mathrm{LCR}]$.

5 Asia: Bachelet Alarmed by Clampdown on Freedom of Expression During COVID-19, U.N. HuM. RTS. (June 3, 2020), https://www.ohchr.org/EN/NewsEvents/Pages/Display News.aspx?NewsID=25920\&LangID=E [https://perma.cc/72JA-N26J] [hereinafter Asia: Bachelet Alarmed]. 
can be difficult to define, even from a purely theoretical perspective. ${ }^{6}$ In practical terms, the truth can be tricky to pin down. ${ }^{7}$ During a demonstration that results in violence, for example, the government's position on what caused the escalation may be entirely different from that of the protesters. ${ }^{8}$ While, in some instances, one party's position may be deliberately dishonest, in others, the competing parties' perspectives may emphasize certain narrative aspects above others. In addition to the inherent challenges of finding a neutral and accurate account of the truth, defining what degree of deviation from the truth warrants prosecution can be difficult. Likewise, the common problem of separating statements of fact from expressions of opinion or perspective further blurs the line between lawful and prohibited speech. ${ }^{9}$ All of these challenges cut against a well-recognized principle of international human rights law: restrictions on speech must be drafted with sufficient precision to enable an individual to regulate their conduct accordingly and must be drafted with limited discretion related to the restriction's execution. ${ }^{10}$

Related to this lack of clarity, the unpredictable nature of misinformation offenses creates a heightened risk of a chilling effect on legitimate speech. ${ }^{11}$ The threat of severe penalty, particularly the threat of imprisonment, further exacerbates the risk of inhibiting

6 Partly in response to the lack of definitional rigor in this space, Claire Wardle and Hossein Derakhshan have proposed a framework whereby "mis-information" is defined as information "that is false, but not created with the intention of causing harm." Wardle and Derakhshan then use the term "information disorder" as a broader term that includes "mis-information," "dis-information," and "mal-information." Claire Wardle \& Hossein Derakhshan, Information Disorder: Toward an Interdisciplinary Framework for Research and Policymaking, COUNCIL OF EUR., at 20-21 (Sept. 27, 2017), https://rm.coe .int/information-disorder-toward-aninterdisciplinary-framework-for-researc/168076277c.

However, while this framework has gained significant academic traction, considerable variation remains regarding these terms' common usage. Often, the terms are used interchangeably. See, e.g., Who Starts Viral Misinformation?, BBC NEwS (May 4, 2020), https://www.bbc.com/news/av/world-52454129 [https://perma.cc/3V5F-6P3Q].

7 Frank Deaver, On Defining Truth, 5 J. MASs Media ETHICs 168, 169 (1990).

8 See, e.g., Philip Bump, Attorney General Barr's Dishonest Defense of the Clearing of Lafayette Square, WASH. POST (June 8, 2020), https://www.washingtonpost.com /politics/2020/06/08/attorney-general-barrs-dishonest-defense-clearing-lafayette-square/ [https://perma.cc/T8TU-D5JX].

9 See, e.g., Rodney W. Ott, Fact and Opinion in Defamation: Recognizing the Formative Power of Context, 58 FORDHAM L. REV. 761 (1990).

10 Rep. of the Hum. Rts. Comm., General Comment No. 34: Article 19 (Freedoms of Opinion and Expression), $\uparrow 25$, U.N. Doc CCPR/C/GC/34 (2011).

11 See Sunday Times v. United Kingdom, 30 Eur. Ct. H.R. (ser. A) at 49 (1979). 
legitimate speech. $^{12}$ The risk may have an especially concerning impact on journalism. Making occasional mistakes may be inevitable for journalists who frequently report on rapidly developing stories. In a robust democracy, criminal punishment is an unreasonable and disproportionate consequence for these unintentional mistakes. Instead, consequences should be limited to a journalist's professional reputation and credibility. Where laws against misinformation exist, they are frequently abused as a mechanism to target journalists, as well as opposition commentators or other critics of the government. ${ }^{13}$

As a consequence of these challenges, international human rights law has generally taken a skeptical view of criminal prohibitions targeting misinformation. In a 2017 Joint Declaration, freedom of expression mandates from the United Nations, the Organization of American States (OAS), the African Commission on Human and Peoples' Rights (ACHPR), and the Organization for Security and Cooperation in Europe (OSCE) emphasized that "the human right to impart information and ideas is not limited to "correct statements." 14 This idea was reaffirmed in a 2020 declaration by special mandates from the U.N., the OAS, and the OSCE. ${ }^{15}$ The U.N. Human Rights Committee regularly cites abusive misinformation provisions in its reporting on national-level freedom of expression challenges. ${ }^{16}$

There is relatively little international jurisprudence that specifically assesses the validity of misinformation laws, but some adverse findings exist where laws have been challenged. In 2018, the Community Court of Justice of the Economic Community of West African States (ECOWAS) found that The Gambia's criminal restrictions targeting false news violated the freedom of expression protections in the

12 Fatullayev v. Azerbaijan, App. No. 40984/07, 2010 Eur. Ct. H.R., qฯ 102-03; http://hudoc.echr.coe.int/eng?i=001-98401 (unpublished).

13 See, e.g., Egypt: Activists Arrested in Dawn Raids, Hum. RTs. Watch (May 13, 2018), https://www.hrw.org/news/2018/05/31/egypt-activists-arrested-dawn-raids [https:// perma.cc/5VEC-FUPZ].

14 International Mechanisms for Promoting Freedom of Expression, "Joint Declaration on Freedom of Expression and 'Fake News,' Disinformation and Propaganda" (Mar. 3, 2017), http://www.oas.org/en/iachr/expression/showarticle.asp?artID =1056\&lID $=1$ [https: //perma.cc/4GKN-JML9].

15 International Mechanisms for Promoting Freedom of Expression, "Joint Declaration on Freedom of Expression and Elections in the Digital Age," CTR. FOR L. \& DEMOCRACY (Apr. 30, 2020), https://www.law-democracy.org/live/wp-content/uploads/2020/04/mandates -decl.2020.elections.pdf [https://perma.cc/J4BB-5D8K].

16 See, e.g., Annual General Assembly Report of the Human Rights Committee, 989 , U.N. Doc. A/50/40 (Oct. 3, 1995); Concluding Observations of the Human Rights Committee: Mauritius, $\uparrow 19$, U.N. Doc. CCPR/C/79/Add.60 (Apr. 4, 1996). 
Revised ECOWAS Treaty, as well as the African Charter on Human and Peoples' Rights and the International Covenant on Civil and Political Rights. ${ }^{17}$ Likewise in 2019, the East African Court of Justice invalidated sections of Tanzania's Media Services Act related to false information dissemination. ${ }^{18}$

A number of other courts have rejected false news laws as incompatible with constitutional freedom of expression guarantees. In Canada, the Supreme Court's decision in R. v. Zunde ${ }^{19}$ held that a Criminal Code provision that prohibited willful publication of a statement or news that the publisher knows is false and that "causes or is likely to cause injury or mischief to a public interest" was incompatible with the country's constitutional freedom of speech protections. The Supreme Court grounded its reasoning in the potential breadth of the prohibition. The 1992 decision also labeled the provision "anachronistic," which is particularly interesting in the context of the current resurgence of global interest in these laws. The Supreme Court of Canada's reasoning in Zundel was particularly influential elsewhere in the Commonwealth, ${ }^{20}$ and successful constitutional challenges against false news laws in Uganda, ${ }^{21}$ Zimbabwe, ${ }^{22}$ and Zambia ${ }^{23}$ all cited the Zundel decision in their reasoning. The United States Supreme Court's decision in United States v. Alvarez, which held that the First Amendment protects false statements of fact, makes it highly unlikely that a misinformation law would survive constitutional challenge in the United States. ${ }^{24}$ Likewise, in Hector v. Attorney-General of Antigua and Barbuda, the Judicial Committee of the Privy Council found that

17 ECOWAS: Federation of African Journalists (FAJ) et al. v. The Gambia, Judgment No. ECW/CCJ/JUD/04/18, p. 61.

18 EACJ: Media Council of Tanzania et al. v. the Attorney General of the United Republic of Tanzania, Reference No. 2 of 2017 p.49. However, there is some ambiguity to this decision, since the Court invalidated the provisions despite also claiming that they appear to be "largely unobjectionable." Id.

19 R. v. Zundel, [1992] 2 S.C.R. 731 (Can.).

$20 \mathrm{Id}$.

21 Onyango-Obbo and Mwenda v. The Attorney General of Uganda, Constitutional Appeal No. 2 of 2002 (11 February 2004).

22 Chavunduka and Choto v. Minister of Home Affairs \& Attorney General of Zimbabwe, (May 22, 2000), Judgment No. S.C. 36/2000 (Supreme Court of Zimbabwe).

23 Chipenzi and Others v. The People, (HPR/03/2014) [2014] ZMHC 112, at J23-J25 (Dec. 3, 2014).

24 United States v. Alvarez, 567 U.S. 709 (2012). 
Antigua and Barbuda's law against making false statements violated freedom of expression protections in that country's constitution. ${ }^{25}$

Although the limited amount of international jurisprudence makes it difficult to come to a categorical conclusion that misinformation laws are always illegitimate, the preceding examples illustrate that legislation in this space can raise freedom of expression concerns. Concerns about the vague nature of these laws, and the potential for collateral damage to journalism or other forms of legitimate speech, seem to be a recurring theme in debates around criminal laws targeting misinformation.

\section{II}

\section{From a Public Health Crisis to a Human Rights Crisis}

Although debates around the impact the internet has as a vector for misinformation have been ongoing for years, ${ }^{26}$ the current crisis has made governments particularly jittery of potential dangers. In the United Kingdom, conspiracy theories suggesting that COVID-19 is somehow connected to the rollout of $5 \mathrm{G}$ mobile service have led to arson of cell towers. ${ }^{27}$ Other rumors include rumors the United States or Chinese military originally spread the virus for use as a bioweapon, ${ }^{28}$ or that the virus can be cured by avoiding ice cream or even drinking bleach. ${ }^{29}$ More broadly, the pandemic has created a heightened need for people to strictly regulate their behavior, such as mask-wearing and social distancing protocols. ${ }^{30}$ False narratives that muddy the message

25 Hector v. Attorney-General of Antigua and Barbuda, [1990] UKPC 3, at 6.

26 See, e.g., Henry Farrell \& Bruce Schneier, Common-Knowledge Attacks on Democracy, SSRN (Nov. 17, 2018), https://papers.ssrn.com/sol3/papers.cfm?abstract_id $=3273111$ [https://perma.cc/2D78-7CTJ].

27 Mast Fire Probe Amid 5G Coronavirus Claims, BBC News (Apr. 4, 2020), https://www.bbc.com/news/uk-england-52164358 [https://perma.cc/8EY2-RGME].

28 Carlton Reid, Chinese State Newspaper Amplifies Conspiracy Theory That First COVID-19 Patient Was U.S. Cyclist, FORBES (Mar. 26, 2020), https://www.forbes.com /sites/carltonreid/2020/03/26/chinese-state-newspaper-stokes-conspiracy-theory-that-first -covid-19-patient-was-us-cyclist/\#1467c66728dd [https://perma.cc/GT3B-8UP4]; Bill Gertz, Coronavirus May Have Originated in Lab Linked to China's Biowarfare Program, WASH. TIMES (Jan. 26, 2020), https://www.washingtontimes.com/news/2020/jan/26/coronavirus -link-to-china-biowarfare-program-possi/ [https://perma.cc/KC53-X7SV].

29 Zaria Gorvett, No, Drinking Water Doesn't Kill Coronavirus, BBC FuTURE (Mar. 20, 2020), https://www.bbc.com/future/article/20200319-covid-19-will-drinking-water-keep -you-safe-from-coronavirus [https://perma.cc/GTP3-CHV2].

30 Sheryl Gay Stolberg \& Noah Weiland, Fauci, Citing 'Disturbing Surge,' Tells Congress the Virus Is Not Under Control, N.Y. TIMES (July 13, 2020), https://www.nytimes .com/2020/06/23/us/politics/fauci-congress-coronavirus.html [https://perma.cc/5K34-G29Z]. 
around proper safety protocols, or sow distrust in public institutions, may be more dangerous than usual during the current crisis.

However, while some fears of misinformation in the current context are well placed, the pandemic has given rise to an unprecedented global crackdown on freedom of expression. Both Hungary and Thailand now punish the spread of "false information" about the virus or measures against it with up to five years' imprisonment. ${ }^{31}$ In Zimbabwe, the penalty is up to twenty years' imprisonment. ${ }^{32}$ New laws criminalizing COVID-19-related misinformation have also been passed in Algeria, ${ }^{33}$ Namibia, ${ }^{34}$ and at the state level in India. ${ }^{35}$ Some new laws aimed at controlling information flows, like Botswana's Emergency Powers (COVID-19) Regulations, 2020, go even further - they criminalize sharing any information about the COVID-19 pandemic from a source other than the Director of Health Services or the World Health Organization. ${ }^{36}$ As of June 2020, Botswana had charged at least two

31 See Hungary Passes Law Allowing Viktor Orban to Rule by Decree, DEUTSCHE Welle (Mar. 30, 2020), https://www.dw.com/en/hungary-passes-law-allowing-viktor -orban-to-rule-by-decree/a-52956243 [https://perma.cc/QV83-ZEP6]; Thailand: COVID19 Clampdown on Free Speech, HuM. RTS. WATCH (Mar. 25, 2020), https://www.hrw.org /news/2020/03/25/thailand-covid-19-clampdown-free-speech [https://perma.cc/AU7W -HKKA].

32 Public Health (COVID-19 Prevention, Containment and Treatment) (National Lockdown) Order, Statutory Instrument 83 of 2020, s. 14 (Zimbabwe), https://www .veritaszim.net/sites/veritas_d/files/SI\%202020-083\%20Public $\% 20$ Health $\% 20 \% 28$ COVID $-19 \% 20$ Prevention $\% 2 \mathrm{C} \% 20$ Containment $\% 20$ and $\% 20$ Treatment $\% 29 \% 20 \% 28$ National $\%$ 20Lockdown\%29\%20Order\%2C\%202020.pdf [https://perma.cc/Q3MH-T8QP].

33 Melissa Nait Ali, Ce que prévoit l'amendement du code pénal sur les Fake-News et violation du confinement, INTERLIGNES (Apr. 20, 2020), https://www.inter-lignes.com/ce -que-prevoit-lamendement-du-code-penal-sur-les-fake-news-et-violation-du-confinement/; Algeria Blocks 3 News Websites and Criminalizes False News, COMM. то PROTECT JOURNALISTS (Apr. 22, 2020), https://cpj.org/2020/04/algeria-blocks-3-news-websites-and -criminalizes-fa/ [https://perma.cc/7DTN-UYV9].

34 Republic of Namibia, Amendment of State of Emergency COVID-19 Regulations: Namibian Constitution (Proclamation No. 13 of 2020), s. 15(1)(e), http://www.lac.org.na /laws/2020/7180.pdf [https://perma.cc/D6PP-PT5K].

35 Government of Punjab, India, Punjab Epidemic Diseases, COVID-19 Regulations, 2020 (No. 14/7/2020-4Pb4/677), s. 6; Government of Maharashtra, India, The Maharashtra COVID-19 Regulations, 2020 (No. Corona-2020/CR-58/Aarogya-5), s. 6, https://www .maharashtra.gov.in/Site/Upload/Acts\%20Rules/English/Korona\%20Notification\%2014 \%20March\%202020....pdf [https://perma.cc/TBL3-39D9]; Government of National Capital Territory of Delhi, India, Delhi Epidemic Diseases, COVID-19 Regulations, 2020 (No. F. 51/DGHS/PH-IV/COVID-19/202-215), s. 6, https://main.sci.gov.in/pdf/cir/covid19_1403 2020.pdf [https://perma.cc/C5NL-GAAQ].

36 Republic of Botswana, Emergency Powers (COVID-19) Regulations, 2020 (Statutory Instrument No. 61 of 2020), s. 30(3), https://bw.usembassy.gov/wp-content/uploads/sites /125/Emergency-Powers-COVID-19-Regulations-2020.pdf. 
journalists and one opposition politician under the law. ${ }^{37}$ Armenia's emergency declaration contains a similar provision, which has likewise been used to target journalists. ${ }^{38}$

Other countries have used the current crisis as an excuse to ramp up prosecutions of journalists and opposition political figures under existing false news laws. Bangladesh has filed at least 60 cases against more than 100 people under the false news provisions of its Digital Security Act, including 22 journalists and a number of social activists and whistleblowers. ${ }^{39}$ Cambodia has arrested over 20 people, many of them associated with a dissolved opposition party. ${ }^{40}$ Venezuela has detained at least 18 journalists since the start of the pandemic, many under the accusation of incitement of hatred. ${ }^{41}$ In Côte d'Ivoire, a civil court fined a newspaper under Article 173 of the Criminal Code, which prohibits publishing "false information likely to cause panic," after journalists reported on the arrest of two people infected with COVID19. ${ }^{42}$ Journalists have also been arrested in Chad, ${ }^{43}$ Iran, ${ }^{44}$ Myanmar, ${ }^{45}$

37 Sesupo Rantsimako, BPF Spokesman Arrested for Fake News, THE Bots. GAZETTE (Apr. 16, 2020), https://www.thegazette.news/news/bpf-spokesman-arrested-for-fake-news /30891/\#.XtgXsy2Q1p8 [https://perma.cc/AXQ2-6ACB]; Portia Mlilo, Justice Motlhabane Case Postponed to Tuesday, THE VOICE (Aug. 2, 2020), https://news.thevoicebw.com /2020/08/justice-motlhabane-case-postponed-to-Tuesday/ [https://perma.cc/TZA5-TJXJ].

38 Ani Mejlumyan, Armenia Takes Hard Line Against Media Reporting on COVID-19, EURASIANET (Mar. 23, 2020), https://eurasianet.org/armenia-takes-hard-line-against-media -reporting-on-covid-19 [https://perma.cc/JEC2-42PD].

39 Ali Riaz, A Pandemic of Persecution in Bangladesh, Atl. Council (May 11, 2020), https://www.atlanticcouncil.org/blogs/new-atlanticist/a-pandemic-of-persecution-in -bangladesh/.

40 Cambodia: Reporter Jailed for Quoting Hun Sen on COVID-19, HuM. RTS. WATCH (Apr. 10, 2020), https://www.hrw.org/news/2020/04/10/cambodia-reporter-jailed-quoting -hun-sen-covid-19 [https://perma.cc/T8UD-E7FS].

41 Coronavirus en Venezuela: los periodistas y médicos detenidos en el país en medio de la pandemia, BBC NEws (Apr 28, 2020), https://www.bbc.com/mundo/noticias-america -latina-52450803/ [https://perma.cc/7WKP-CDH5].

42 Newspaper Fined for "False Publication" on COVID-19 Status of Inmates, MEDIA FOUND. FOR W. AFR. (Apr. 27, 2020), https://www.mfwa.org/issues-in-focus /newspaper-fined-for-false-publication-about-covid-19/ [https://perma.cc/FJ2H-C6UC].

43 Chadian Police Attack TV Crew Covering Coronavirus Measures, REPS. WiTHOUT BORDERS (Apr. 3, 2020), https://rsf.org/en/news/chadian-police-attack-tv-crew-covering -coronavirus-measures [https://perma.cc/3D8G-VC7B].

44 Iranian Journalists Hounded for Disputing Official Coronavirus Figures, REPS. WiTHOUT BORDERS (Mar. 13, 2020), https://rsf.org/en/news/iranian-journalists-hounded -disputing-official-coronavirus-figures [https://perma.cc/YQ9U-AJHA].

45 Myanmar Journalist Jailed for Two Years for Reporting COVID-19 Death, REPS. WithOUT BORDERS (May 25, 2020), https://rsf.org/en/news/myanmar-journalist-jailed -two-years-reporting-covid-19-death [https://perma.cc/45TP-LU9M]. 
the Philippines, ${ }^{46}$ and Egypt, ${ }^{47}$ the last of which has a particularly extensive record of abusing false news laws to target critical voices. A number of cases stemmed from reports that uncovered governmental malfeasance or negligence, such as officials refusing to obey quarantine orders ${ }^{48}$ or systemic underreporting of COVID-19 infection and death rates. ${ }^{49}$ In addition to false news legislation, governments have cracked down on alleged virus misinformation using laws prohibiting hate speech, ${ }^{50}$ public intimidation, ${ }^{51}$ and, in the case of India, the colonial-era Epidemic Diseases Act, $1897 .{ }^{52}$

Still, other governments have expanded their control over the information discourse in different ways. Romania's state of emergency proclamation does not include jail terms, but does grant the government sweeping powers to order that false material be removed from public view. ${ }^{53}$ Governments in Nepal and Myanmar have ordered telecommunications providers to block news websites accused of

46 Two Reporters Charged for Spreading 'False Information' About COVID-19 in the Philippines, COMM. TO PROTECT Journalists (Apr. 3, 2020), https://cpj.org/2020/04 /two-reporters-charged-for-spreading-false-informat.php [https://perma.cc/7DJ8-2YAA]; See Statement on Government Requiring Journalists to Get PCOO Accreditation to Be Exempted from Community Quarantine, CTR. FOR MEDIA FREEDOM \& RESP. (Mar. 20, 2020), https://cmfr-phil.org/statements/statement-on-government-requiring-journalists -to-get-pcoo-accreditation-to-be-exempted-from-community-quarantine/ [https://perma.cc /SC78-527P].

47 Qassem Mohammed, Egypt Arrests 10 Journalists Since Coronavirus Outbreak, ANADOLU AGENCY (May 22, 2020), https://www.aa.com.tr/en/africa/egypt-arrests-10 -journalists-since-coronavirus-outbreak/1850942 [https://perma.cc/P3FU-E8UQ].

48 See, e.g., Mary Wambui, Police Hold Blogger Nyakundi over COVID-19 Twitter Post, DAILY NATION (March 27, 2020), https://nation.africa/kenya/news/police-hold-blogger -nyakundi-over-covid-19-twitter-post-281064 [https://perma.cc/C5GA-P8PH].

49 REPS. WITHOUT BORDERS, supra note 44.

50 Detienen a hombre por el delito de actos de odio en Guayaquil, METRO ECUADOR (Apr. 6, 2020), https://www.metroecuador.com.ec/ec/noticias/2020/04/06/detienen-hombre -comentarios-negativos-redes-sociales-guayaquil.html [https://perma.cc/XNY6-3SZ7].

51 See Coronavirus en la Argentina: "Voy a contagiarlos a todos", el video de un santafesino que terminó en denuncia, LA NACION (Mar. 26, 2020), https://www .lanacion.com.ar/sociedad/coronavirus-argentina-voy-contagiarlos-todos-video-santafesino -nid2347405 [https://perma.cc/XD79-3G2N].

52 Republic of India, Epidemic Diseases Act, 1897 (Act. No. 3 of 1897).

53 Marcel Gascón Barberá, Romania's State of Emergency Raises Media Freedom Concerns, BALKAN INSIGHT (Mar. 31, 2020), https://balkaninsight.com/2020/03/31 /romanias-state-of-emergency-raises-media-freedom-concerns/. 
hosting misinformation. ${ }^{54}$ Jordan even suspended the printing of newspapers, alleging that the printing process could spread the virus. ${ }^{55}$

While it is easy to recognize the potential harm from health misinformation in the current context, these examples demonstrate how broadly worded laws aimed at preventing the spread of conspiracy theories can be repurposed to blunt critical reporting, opposition speech, whistleblowing, or even accurate observations of how state agencies are mismanaging the crisis. Governments around the world are treating the pandemic as a blank check to crack down on dissent, with the potential for a lasting shift in how freedom of expression is understood and protected. ${ }^{56}$

III

\section{Protecting SPEeCH IN TIMES OF CRISIS}

Periods of exceptional societal stress commonly affect our collective calculus in determining what kinds of human rights restrictions are justified. ${ }^{57}$ However, temporary measures adopted in times of crisis often become normal. ${ }^{58}$ This is partly because people become inured to the new rules, or another potential emergency is always around the corner, which may counter attempts to ease restrictions. ${ }^{59}$

The current COVID-19 pandemic presents difficult trade-offs between safeguarding the right to freedom of expression and protecting public health. ${ }^{60}$ In considering the applicability of international human rights law to these exceptional circumstances, it is useful to refer back to the standards spelled out in key human rights documents for

54 Thompson Chau, Telenor Follows Myanmar Orders to Block Alleged 'Fake News' Sites, MYANMAR TIMES (Mar. 31, 2020), https://www.mmtimes.com/news/telenor-follows -myanmar-orders-block-alleged-fake-news-sites.html; Press Release, Press Council of Nepal, Notice for Media's Attention and Action (Mar. 30, 2020), http://www.presscouncil nepal.org/np/2020/03/2771.

55 Middle East Governments Clamp Down on Coronavirus Coverage, REPS. WiTHOUT BORDERS (Mar. 27, 2020), https://rsf.org/en/news/middle-east-governments-clamp-down -coronavirus-coverage.

56 Richard Burchill, When Does an Emergency Threaten the Life of the Nation? Derogations from Human Rights Obligations and the War on International Terrorism, 8 Y.B. N.Z. JURIS. 99, 115 (2005).

57 Emerson, supra note 1.

58 Burchill, supra note 56.

59 See Kim L. Scheppele, Law in a Time of Emergency: States of Exception and the Temptations of 9/11, 6 U. PA. J. CONST. L. 1001 (2004).

60 Kaye, supra note 3, ๆฯ 15-16. 
derogating from the scope of obligations. ${ }^{61}$ The most well known of these is in Article 4 of the International Covenant on Civil and Political Rights (ICCPR) ${ }^{62}$ which allows governments facing a public emergency that "threatens the life of the nation" to take measures that, under normal circumstances, would violate certain human rights obligations. ${ }^{63}$ The underlying caveats include that the government must properly declare the emergency and the intent to derogate, must clearly define an end point for the exceptional measures, and must justify the measures as "strictly required by the exigencies of the situation." ${ }^{44}$ The ICCPR further mandates that governments wishing to avail themselves of this option must inform the U.N. Secretary-General of this desire and the date the derogation terminates. ${ }^{65}$ Article 15 of the European Convention on Human Rights ${ }^{66}$ and Article 27 of the American Convention on Human Rights include similar processes. ${ }^{67}$

As of September 2020, a search of the United Nations Treaty Collection shows that twenty-one countries notified the U.N. Secretary-General of an intent to restrict the applicability of certain provisions of the ICCPR under the Article 4 framework as a result of COVID-19. ${ }^{68}$ Only one of these countries, Colombia, targeted their notification toward the Article 19 protection of freedom of expression, which limits the formal applicability of this process to the policies discussed in Part II. ${ }^{69}$ Nonetheless, the general formula that these

61 International Covenant on Civil and Political Rights art. 4, Dec. 1966, 999 U.N.T.S. 171.

$62 \mathrm{Id}$.

$63 \mathrm{Id}$.

64 For an extensive discussion of the contours of justified derogations from human rights norms in times of emergency, see U.N. Commission on Human Rights (UNCHR), The Siracusa Principles on the Limitations and Derogation Provisions in the International Covenant on Civil and Political Rights, U.N. Doc. E/CN.4/1985/4, Annex, (Sept. 28, 1984).

$65 \mathrm{Id}$. at 11.

66 See Convention for the Protection of Human Rights and Fundamental Freedoms, as amended by Protocols Nos. 11 and 14, Nov. 4, 1950, E.T.S. 005 (entered into force Sept. 3, 1953).

67 See American Convention on Human Rights, T.S. 36, Nov. 22, 1969, (entered into force July 18, 1978).

68 The countries that have invoked COVID-19 to trigger an emergency declaration under the ICCPR are Guatemala, Latvia, Estonia, Armenia, Ecuador, Romania, Peru, Georgia, Palestine, Chile, Kyrgyzstan, El Salvador, San Marino, Moldova, Argentina, Thailand, Ethiopia, Senegal, Namibia, Paraguay, and the Dominican Republic. The full database of depositary notifications is available at https://treaties.un.org/Pages/CNs.aspx? cnTab=tab2\& clang=_en.

69 U.N. Secretary-General, Depositary Notification (Mar. 25, 2020), https://treaties.un .org/doc/Publication/CN/2020/CN.131.2020-Eng.pdf. 
documents apply is useful to understanding and interpreting international human rights standards in the context of an emergency. In essence, the ICCPR standard of "strict necessity" may be viewed as a narrower formulation of the traditional three-part test for restrictions on speech, mandating that the exigencies of the situation require the intrusions and are proportional to the danger, both in terms of their degree and their duration. ${ }^{70}$

\section{IV \\ ASSESSING GLOBAL RESPONSES}

As assessed against the standards spelled out in the preceding parts, ${ }^{71}$ international mechanisms are justified in expressing concern with the crackdown. ${ }^{72}$ First, while some of the revised laws spelled out in this Article are explicitly temporary in their application, ${ }^{73}$ this is not always the case.$^{74}$ For example, while most of the provisions in Zimbabwe's emergency order are explicitly limited to the period corresponding to the national lockdown, the restrictions on "false reporting" have no such sunset. ${ }^{75}$ Concerns that the impacts of COVID responses could outlast the current pandemic compound in cases where misinformation enforcement is based not on COVID-related legislation but on a newly expansive interpretation of laws that were already on the books. ${ }^{76}$ Given the documented abuses of these laws to target journalists and

70 UNCHR, supra note 64.

71 See supra Part I, Part III.

72 Asia: Bachelet Alarmed, supra note 5; IACHR and Its SR FOE Express Concern About Restrictions on Freedom of Expression and Access to Information in States' Response to the COVID-19 Pandemic, Press Release R78/20 (Apr. 18, 2020), http://www .oas.org/en/iachr/expression/showarticle.asp?artID=1173\&lID=1 [https://perma.cc/Q7MD -9AJT]; Kaye, supra note 3, ๆๆ 48-49.

73 See, e.g., Republic of Namibia, Amendment of State of Emergency COVID-19 Regulations: Namibian Constitution (Proclamation No. 13 of 2020), s. 15(1)(e), http://www .lac.org.na/laws/2020/7180.pdf.

74 Public Health (COVID-19 Prevention, Containment and Treatment) (National Lockdown) Order, SI 83 of 2020 (Zimbabwe), https://www.veritaszim.net/sites/veritas_d /files/SI\%202020-083\%20Public\%20Health\%20\%28COVID-19\%20Prevention\%2C\%20 Containment $\% 20$ and $\% 20$ Treatment $\% 29 \% 20 \% 28$ National\%20Lockdown $\% 29 \% 20$ Order $\% 2 \mathrm{C} \% 202020$.pdf [https://perma.cc/6Q3H-6AWU].

$75 \mathrm{Id}$.

76 Bhavya Dore, Fake News, Real Arrests, FOREIGN POL'y (Apr. 17, 2020), https:// foreignpolicy.com/2020/04/17/fake-news-real-arrests/ [https://perma.cc/LAL6-DLEH]. See also Detienen a hombre por el delito de actos de odio en Guayaquil, supra note 50; See also Coronavirus en la Argentina: "Voy a contagiarlos a todos", el video de un santafesino que terminó en denuncia, supra note 51. 
other critical voices, normalizing this approach to combating false speech would be disastrous for global freedom of expression. ${ }^{77}$

Second, many of the restrictions are framed in extremely broad terms beyond the narrow confines of information likely to cause actual harm. ${ }^{78}$ A particularly extreme example involves laws criminalizing statements that diverge in any way from the official government line, effectively granting authorities the power to enforce their own centralized version of the truth. ${ }^{79}$ Key defenses that would prevent an undue chilling effect, such as allowing a defendant to demonstrate their honest but mistaken belief that the content was correct, are generally absent from the laws discussed in this Article. ${ }^{80}$

Third, disproportionate sanctions are another common feature of the crackdown. ${ }^{81}$ In 2000, the U.N. Special Rapporteur on Freedom of Expression stated in clear terms that, with the exception of cases involving racist or discriminatory comments or calls to violence, "imprisonment as punishment for the peaceful expression of an opinion constitutes a serious violation of human rights." 82 Even in an emergency, it seems doubtful that multiyear jail terms could possibly be considered necessary or proportionate.

This analysis paints a picture of a regressive environment for global freedom of expression; an environment that seems likely to persist as the pandemic drags on and could even affect global freedom of expression norms beyond the current crisis. ${ }^{83}$ Given freedom of expression's importance as a core democratic right, and in the

77 Supra Part II.

78 See, e.g., Thailand: COVID-19 Clampdown on Free Speech, supra note 31; Ani Mejlumyan, supra note 31.

79 Republic of Botswana, Emergency Powers (Covid-19) Regulations, 2020 (Statutory Instrument No. 61 of 2020), s. 30(3), https://bw.usembassy.gov/wp-content/uploads/sites /125/Emergency-Powers-COVID-19-Regulations-2020.pdf [https://perma.cc/DAJ7-P5Z2].

80 See, e.g., Republic of Namibia, Amendment Of State Of Emergency Covid-19 Regulations: Namibian Constitution (Proclamation No. 13 of 2020), s. 15(1)(e), http://www .lac.org.na/laws/2020/7180.pdf.

81 See Hungary Passes Law Allowing Viktor Orban to Rule by Decree, supra note 31; see also Thailand: COVID-19 Clampdown on Free Speech, supra note 31.

82 Annual Report to the U.N. Commission on Human Rights, Promotion and Protection of the Right to Freedom of Opinion and Expression, 18 January 2000, U.N. Doc. E/CN.4 $12000 / 63$, \ 205.

83 See Siobhan Roberts, This Is the Future of the Pandemic, N.Y. TimEs (May 8, 2020), https://www.nytimes.com/2020/05/08/health/coronavirus-pandemic-curve-scenarios.html [https://perma.cc/KP7P-WVQR]. 
context of a broader regression of global democratic values, ${ }^{84}$ considering alternative solutions to COVID-19's misinformation challenges is important.

\section{V}

\section{FINDING SOLUTIONS}

Although the current backsliding on freedom of expression is concerning, health misinformation unquestionably poses a real risk in the context of the COVID-19 pandemic. ${ }^{85}$ As a result, critiques of the impact of governmental approaches to countering this "infodemic" give rise to a need for careful analysis as to how governments can safeguard their populations in a way that is less intrusive against core human rights. This Part considers two general options for mitigating the harm of governmental responses. The first is to narrow and clarify the scope of criminal content rules targeting misinformation. The second is to focus efforts toward increasing the quality and accuracy of the discourse.

\section{A. Narrowing and Clarifying the Prohibitions}

It is worth recalling that a cardinal rule of human rights law is that restrictions affecting the right to freedom of expression should be as carefully targeted as possible. ${ }^{86}$ Given that overbreadth is one of the most common problems noted in Part IV of this Article, it stands to reason that more carefully tailored restrictions would go some way toward mitigating the harm to freedom of expression. In this vein, although there are often grave concerns associated with laws criminalizing misinformation, certain narrow and specific versions of these prohibitions have survived judicial scrutiny. In particular, courts have repeatedly upheld laws criminalizing Holocaust denial. ${ }^{87}$ Similarly, in Faurisson v. France, the U.N. Human Rights Committee

84 See Michael J. Abramowitz, Democracy in Crisis, FreEdOM HouSE (2018), https:// freedomhouse.org/report/freedom-world/2018/democracy-crisis [https://perma.cc/6X2S -P3B8].

85 See U.N. Tackles 'Infodemic' of Misinformation and Cybercrime in COVID-19 Crisis, UNDGC (Mar. 31, 2020), https://www.un.org/en/un-coronavirus-communications-team /un-tackling-'infodemic'-misinformation-and-cybercrime-covid-19 [https://perma.cc/J53B $-28 \mathrm{KP}]$.

86 Rep. of the Hum. Rts. Comm., supra note 10, ๆ 25.

87 See Pastörs v. Germany, 2019 Eur. Ct. H.R. 330, https://laweuro.com/?p=9877 [https://perma.cc/PC7V-S5B5]. 
upheld a French law that prohibited denying crimes against humanity because of the specific nexus with anti-Semitism. ${ }^{88}$

A key difference between the laws targeting Holocaust denial and the responses to COVID-19 outlined in the preceding parts concerns the breadth of prohibited content. This principle also relates to the ICCPR standard that emergency interferences should be "strictly required by the exigencies of the situation." 89 A narrower and more specifically defined law naturally carries a lower probability of being misused or of creating a problematic chilling effect around legitimate speech. ${ }^{90}$

As applied to the current context, narrowing the scope of restrictions targeting COVID-19-related misinformation could mean only prohibiting statements that are likely to directly compromise treatment or public health efforts, such as peddling claims about a fraudulent cure or actively attempting to subvert public health protocols.

Constructing the offense along these lines also keeps cases focused on objectively verifiable areas of the discourse, such as the efficacy of a particular drug. The relatively narrow band of speech that such an offense might target also mitigates the harm from governments effectively centralizing their own version of the truth. Likewise, this framing mitigates the potential for a harmful chilling effect, since such a formulation would leave out policy criticisms of official responses to the crisis. This is also consistent with the Human Rights Committee's position that governments should never curtail freedom of opinion, even during a state of emergency. ${ }^{91}$

While narrowing the scope of content restrictions would help to mitigate their potential collateral damage, this approach still faces technical challenges to its implementation as a solution to the misinformation problem. Ever since the spread of the internet as a primary avenue for popular discourse, governments have faced a constant struggle to enforce content rules in the online space. ${ }^{92}$ This is

88 U.N. Hum. Rts. Comm., Robert Faurisson v. France, U.N. Doc. CCPR/C/58/D /550/1993 (Dec. 16, 1996), http://hrlibrary.umn.edu/undocs/html/VWS55058.htm [https:// perma.cc/3JGQ-WQXV].

$89 \mathrm{UNCHR}$, supra note 64 , at 5.

90 Sunday Times v. United Kingdom, 30 Eur. Ct. H.R. (ser. A) at 49 (1979).

91 See Rep. of the Hum. Rts. Comm., supra note 10, $\uparrow \uparrow$ 5, 11.

92 The ongoing struggles to enforce copyright over the past two decades are a good example of this challenge, though similar problems persist across nearly every other type of prohibited content. See, e.g., Annemarie Bridy, Is Online Copyright Enforcement 
partly due to the enormous volumes of speech that flow across the internet every day, as well as the technical challenges in tracing information back to its source. ${ }^{93}$ While governments may use criminal content restrictions to target particularly egregious or harmful cases, it seems doubtful that they can ever be enforced with sufficient resources to make a dent in the broader problem. In other words, the problem with criminal restrictions targeting misinformation is not merely that the restrictions can have an outsized impact on legitimate speech. Rather, the problem is that their scope for positively affecting the discourse is limited. Given the well-documented challenges of enforcing content online, even against clearly defined harms like child sexual abuse material, ${ }^{94}$ the broader efficacy of the criminal law as a mechanism to stamp out misinformation is dubious. Such efforts will also do little to stem the tide of false information that senior officials are perpetrating. ${ }^{95}$ Rather than focusing on negative efforts to restrict harmful speech, positive efforts to improve the visibility and quality of the information discourse are a more promising avenue of engagement.

\section{B. Positive Solutions}

In order to promote quality and trust in the information discourse, a better solution than seeking to stem the flow of misleading information is to increase the dissemination of accurate and high-quality information. While it may sound trite to suggest that the best answer to bad speech is more speech, such an idea takes on a renewed import during a public health crisis, given the importance of both public trust

Scalable?, 13 VAND. J. ENT. \& TECH. L. 695 (2011), https://papers.ssrn.com/sol3/papers .cfm?abstract id=1739970 [https://perma.cc/4FHJ-W85F]; Jennifer Stewart, If This Is the Global Community, We Must Be on the Bad Side of Town: International Policing of Child Pornography on the Internet, 20 Hous. J. INT'L LAW 205, 211 (1997), https://heinonline .org/HOL/Page?handle=hein.journals/hujil20\&div=11\&id=\&page=\&collection=journal s [https://perma.cc/2YMM-J9CP].

93 See Chengcheng Shao et al., The Spread of Low-Credibility Content by Social Bots, 9 NATURE COMMC'NS 1 (2018).

94 Stewart, supra note 92.

95 See, e.g., Kurt Wagner, Facebook, Twitter, YouTube Remove Posts From Bolsonaro, BLOOMBERG (Mar. 30, 2020), https://www.bloomberg.com/news/articles/2020-03-31 /facebook-twitter-pull-misleading-posts-from-brazil-s-bolsonaro [https://perma.cc/YG6E -6WMT]; see Kim Lyons, Twitter Removes Tweets by Brazil, Venezuela Presidents for Violating COVID-19 Content Rules, THE VERGE (Mar. 30, 2020), https://www.theverge .com/2020/3/30/21199845/twitter-tweets-brazil-venezuela-presidents-covid-19-corona virus-jair-bolsonaro-maduro [https://perma.cc/S46G-PWLS]; see Rebecca Shabad, Twitter Removes Tweet Highlighted by Trump Falsely Claiming COVID-19 'Cure,' NBC NEwS (July 28, 2020), https://www.nbcnews.com/politics/donald-trump/twitter-removes-tweet -highlighted-trump-falsely-claiming-covid-cure-n1235075 [https://perma.cc/U2PP-PBLU]. 
and accountability. ${ }^{96}$ There are two basic components to a positive response to misinformation. The first is to promote the dissemination of quality and trustworthy information, particularly from official sources. The second is to ensure that positive speakers have the resources and support to counter misinformation.

State efforts promoting quality and trustworthy information must begin with a strong commitment to transparency. While it is understandable that governments might want to exert more control over information flows in times of crisis, such instincts are counterproductive. Rumor and misinformation thrive in an environment of secrecy. Conversely, an open and expressive environment fosters public trust in institutions. ${ }^{97}$ This is true even where transparency exposes corruption or mismanagement. ${ }^{98}$ While such revelations can be damaging to institutional reputations in the short term, they ultimately benefit public confidence insofar as they help to identify and resolve these problems. Certainly, a context in which institutional challenges are openly confronted is more conducive to public trust than one where they are covered up. ${ }^{99}$

Freedom of information, right to information, or access to information legislation are particularly vital mechanisms for ensuring a steady and reliable flow of information to the public. Governments under pressure should aim to bolster these systems as a way of promoting public trust. ${ }^{100}$ Unfortunately, under the current pandemic the opposite trend appears present; some governments have suspended the application of transparency rules, particularly the right to file information requests. ${ }^{101}$ In Honduras and Bangladesh, for example, oversight bodies suspended appeals processes regarding right to

96 See Whitney v. California, 274 US 357 (1927), https://supreme.justia.com/cases /federal/us/274/357/ [https://perma.cc/D84F-ETSE].

97 Kaye, supra note 3, ๆ 18.

98 Id. $\ 31$.

99 Id. 918.

100 See Maintaining Human Rights During Health Emergencies: Brief on Standards Regarding the Right to Information, CTR. FOR L. \& DEMOCRACY 20 (May 27, 2020), https:// www.law-democracy.org/live/wp-content/uploads/2020/05/RTI-and-COVID-19-Briefing .20-05-27.Final_.pdf [https://perma.cc/V8EM-N8UC].

101 See COVID-19 Tracker, CTR. FOR L. \& DEMOCRACY \& ACCESS INFO EUROPE (Apr. 6, 2020), https://www.rti-rating.org/covid-19-tracker/. 
information requests, effectively removing any recourse for wrongfully denied or delayed responses. ${ }^{102}$

While, in some cases, government agencies frame the suspensions as part of a broader government shutdown of public-facing operations, in other instances government agencies appear to be using the pandemic as an excuse to deprioritize their transparency obligations. ${ }^{103}$ In mid-March, the Federal Bureau of Investigation announced that they were suspending their online freedom of information requesting portal and would only process requests received by regular mail. ${ }^{104}$ The shift away from digital requests and toward mail requests requires staffers to physically receive items, which seems difficult to justify in the context of a global shift toward remote work. Certainly, the shift appears to run counter to directives being issued across the United States for citizens to avoid unnecessarily leaving their homes. ${ }^{105}$

Obviously, there will be certain processes that governments are unable to carry out during the pandemic, such as where offices are completely closed and records are inaccessible remotely. However, working to bridge these gaps should be a priority in order to ensure that traditional record keeping and open data standards are maintained in the COVID-19 era, particularly in areas of operation related to the government's response to the crisis.

At a time when public trust is vital to an effective pandemic response, governments should view responding to information requests as an obligation that should be prioritized. Rather than seeing freedom of expression and the right to information as values that compete against measures to combat COVID-19, governments should recognize the core roles that transparency and accountability play in maintaining

102 Shamsul Bari \& Ruhi Naz, RTI/FOI Acts: Another Victim of the COVID-19 Pandemic, THE DAILY STAR (May 15, 2020), https://www.thedailystar.net/opinion /news/rtifoi-acts-another-victim-the-covid-19-pandemic-1902607 [https://perma.cc/GW2F -C3D9]; Honduras, Communication, INST. OF ACCESS TO PUB. INFO. (Mar. 29, 2020), https://pbs.twimg.com/media/EUVCoAjWsAAv4gX?format=jpg\&name=medium [https:// perma.cc/8CHU-P68S].

103 For example, in March, Hawaii suspended the application of its Uniform Information Practices Act entirely. Supplementary Emergency Proclamation of Mar. 16, 2020, https://governor.hawaii.gov/wp-content/uploads/2020/03/2003109-ATG_COVID-19 -Supplementary-Proclamation-signed.pdf [https://perma.cc/GXX8-AWD7].

104 See Freedom of Information Act (FOIA) Processing Changes Due to COVID-19: In Brief, CONG. RSCH. SERV. (Mar. 27, 2020), https://fas.org/sgp/crs/secrecy/R46292.pdf [https://perma.cc/GY3D-23WP].

105 Sarah Mervosh, Denise Lu \& Vanessa Swales, See Which States and Cities Have Told Residents to Stay at Home, N.Y. TIMES (Apr. 20, 2020), https://www.nytimes.com /interactive/2020/us/coronavirus-stay-at-home-order.html [https://perma.cc/9KBN-YMK5]. 
public confidence. As Glenn Cohen, a bioethics expert at Harvard Law School, noted, "Public health depends a lot on public trust. If the public feels as though they are being misled or misinformed their willingness to make sacrifices - in this case social distancing - is reduced."106

Operations that seek to build media literacy, or otherwise empower actors such as journalists or fact-checking organizations, are also valuable, proactive solutions to combat misinformation. Studies show that building media literacy is a key component to promoting popular resilience against misinformation. ${ }^{107}$ While these solutions tend to be longer term and structural, and therefore more difficult to deploy in the context of a sudden crisis, there have been some moves to operationalize more rapid responses to the spread of misinformation. The CivActs campaign (a global movement that works to counter misinformation through coordinating responses from journalists and civil society) is particularly noteworthy in this regard; CivActs currently runs campaigns to counter COVID-related misinformation in Nepal, Pakistan, South Africa, Nigeria, Mali, and Niger. ${ }^{108}$ However, initiatives like CivActs require a robust civil society environment in which to operate, including the sorts of human rights protections that are at risk as a consequence of the proliferation of vague and repressive anti-misinformation laws. In other words, measures that crackdown on freedom of expression are not only problematic in their own right but also could serve to close off potential positive responses to misinformation.

In April 2020, the U.N. Human Rights Committee reminded parties to the International Covenant on Civil and Political Rights of their obligation to avoid derogating from the applicability of certain rights, including the right to freedom of expression, where other measures were available to achieve their public policy objectives. ${ }^{109}$ Likewise, the U.N. Committee on Economic, Social and Cultural Rights

106 Thomas Fuller, How Much Should the Public Know About Who Has the Coronavirus?, N.Y. TIMES (Mar. 28, 2020), https://www.nytimes.com/2020/03/28/us /coronavirus-data-privacy.html.

107 See Marin Lessenski, Just Think About It. Findings of the Media Literacy Index 2019, OPEN SOC'Y INST. SOFIA (Nov. 2019), https://osis.bg/wp-content/uploads/2019/11 /MediaLiteracyIndex2019_-ENG.pdf [https://perma.cc/HF2N-H853].

108 Coronavirus CivActs Campaign, CIVACTS, https:/civacts.org/civactscampaign/ [https://perma.cc/C7H4-ML65] (last visited Mar. 7, 2021).

109 See U.N. Hum. Rts. Council, Statement on Derogations from the Covenant in Connection with the COVID-19 Pandemic, U.N. Doc CCPR/C/128/2 (2020), at ๆ 2(c), https://www.ohchr.org/Documents/HRBodies/CCPR/COVIDstatementEN.pdf. 
emphasized the importance of public participation in public health conversations and initiatives, and warned against governments seeking to crack down on discussions in this space. ${ }^{110}$ While none of the solutions offered in this section are a panacea, they present avenues to countering misinformation that are more likely to have an impact than a heavy-handed crackdown on speech-without the harmful consequences to core democratic values.

\section{CONCLUSION}

Although harm to freedom of expression has not been the most dramatic impact of the current pandemic, the global shift away from international human rights standards may turn out to be one of its most pernicious and lasting legacies. This conceptual shift accompanies an increasingly common narrative regarding the supposed superiority of closed or repressive systems of government in responding to the pandemic. ${ }^{111}$ This perspective relies on a highly selective view of the global landscape that ignores, for example, atrocious failures to contain the virus in Iran. ${ }^{112}$ Some have even pointed to China as an example of the benefits of mechanisms of tight social control, even though these restrictions have, at best, been a double-edged sword. ${ }^{113}$ For example, Li Wenliang, the Wuhan doctor whom the government has now lionized for his early attempts to sound an alarm about the virus, was originally arrested for his actions. ${ }^{114}$

110 See U.N. Comm. on Econ. Soc. \& Cultural Rts., General Comment No. 14: The Right to the Highest Attainable Standard of Health, U.N. Doc E/C.12/2005/4 (2000), 934.

111 See, e.g., Philip J. Heijmans, Singapore Contained Coronavirus. Could Other Countries Learn from Its Approach?, WORLD ECON. F. (Mar. 5, 2020), https://www .weforum.org/agenda/2020/03/singapore-response-contained-coronavirus-covid19-outbreak/ [https://perma.cc/KG86-H7BU]; see Mary Ilyushina, How Russia Is Using Authoritarian Tech to Curb Coronavirus, CNN (Mar. 29, 2020), https://www.cnn.com/2020/03/29/europe /russia-coronavirus-authoritarian-tech-intl/index.html [https://perma.cc/H3NT-C77X].

112 See Michelle Mark, The Coronavirus Has Caused a Full Breakdown in Iran, with an Unknown Death Toll, Infected Leaders, and Massive Burial Pits Visible from Space, BUS. INSIDER (Mar. 17, 2020), https://www.businessinsider.com/iran-coronavirus-covid19 -deaths-cases-updates-2020-3.

113 Kim Hjelmgaard, Eric J. Lyman \& Deirdre Shesgreen, This Is What China Did to Beat Coronavirus. Experts Say America Couldn't Handle It, USA TODAY (Apr. 1, 2020), https://www.usatoday.com/story/news/world/2020/04/01/coronavirus-covid-19 -china-radical-measures-lockdowns-mass-quarantines/2938374001// [https://perma.cc/3FX2 -29T8].

114 Bill Bostock, China Declared Whistleblower Doctor Li Wenliang a 'Martyr' Following a Local Campaign to Silence Him for Speaking Out About the Coronavirus, BUS. INSIDER (Apr. 3, 2020), https://www.businessinsider.com/coronavirus-china-li-wenliang -whistleblower-doctor-martyr-2020-4 [https://perma.cc/6849-G4VP]. 
During this time of crisis, states should cleave to their constitutional and human rights values not only for moral reasons but also for practical ones. It is understandable that governments, feeling particularly vulnerable, might seek to blunt criticism. Likewise, the public's requests for information must seem, to many officials, like a particularly annoying or frivolous exercise given the major threats that they are facing. But critical reporting and public oversight are valuable tools to improving government administration and fostering public trust, both of which are needed now more than ever. 
